\title{
Governing plural policing provision: legal perspectives, challenges and ideas
}

\author{
Philip C. Stenning and Clifford D. Shearing
}

Despite the continued existence of private initiatives after 1829, it has generally been assumed that policing is an inherently public good, whose provision has to reside in the hands of a single, monopoly supplier, the state.

- Les Johnston, The Rebirth of Private Policing (Routledge 1992) 25.

[The challenges posed by plural policing] demand, in particular, a renewed role for institutions of government, not as large, unwieldy providers seeking to swallow up the multiplicity of policing forms that presently exist (that world has, in all likelihood, gone for good), but as active regulators whose task is to ensure that 'public interest' considerations pertaining to such matters as equity and democratic deliberations are sustained in the face of multi-organizational, fragmented policing systems. It is hard to envisage any agency other than the state with the capacity to undertake this role. (Emphasis in original)

- Ian Loader, 'Plural Policing and Democratic Governance' (2000) 9(3) Social \& Legal Studies 323, 336.

It is important to distinguish between the ideas of 'police' and 'policing'. 'Police' refers to a particular kind of social institution, while policing implies a set of processes with specific social functions. 'Police' are not found in every society, and police organizations and personnel can have a variety of shifting forms. 'Policing', however, is arguably a necessity in any social order, which may be carried out by a number of different processes and institutional arrangements. A state-organized specialist 'police' organization of the modern kind is only one example of policing.

- Robert Reiner, The Politics of the Police (4th edn, Oxford University Press 2010), 3-4. 
It is, of course, not customary to begin a chapter with quotes from three authors. We have done so because the quoted passages epitomize so concisely a debate that has been going on among policing scholars and policy makers in the United Kingdom and several other countries for about the last 30 years. This debate has centred around four related, fundamental questions: What is 'policing'? Who can legitimately be thought of as 'policing providers'? How, and by whom should policing provision be governed in an era of plural provision, involving non-state as well as state providers? And what principles should underpin the answers to these three questions? This debate has not been confined to policing scholars and policy-makers in the United Kingdom (UK). In this chapter, however, we focus primarily on the UK debate because UK (and in particular English) policing scholars and policy-makers have played such a leading role in raising and addressing these questions, and have had such a significant influence over similar debates in other common law countries around the world. In focusing our attention on governance we, like Parker et al., $2004^{1}$, define governance as actions intended to shape the flow of events) of police provision. We will be exploring debates about how best to shape policing provision with a particular emphasis on the role of legal and other forms of regulation in shaping the activities of policing providers.

In this chapter we review where this debate has got to in the second decade of the twentyfirst century, and make some suggestions as to directions that might be taken on these issues in the coming years. We start by considering those four questions.

\section{WHAT IS 'POLICING’?}

As the quote from Les Johnston's seminal 1992 book makes clear, prior to the 1980s this was a question that was rarely asked, let alone seriously discussed, in mainstream police literature and

\footnotetext{
${ }^{1}$ Parker, Christine, Colin Scott, Nicola Lacey, and John Braithwaite. 2004. "Introduction.” Pp. 1-12 in Regulating Law, edited by C. Parker, C. Scott, N. Lacey, and J. Braithwaite. Oxford: Oxford University Press.
} 
policy, which focused almost exclusively on 'the public police' (perceived by the public, as one of the late Carl Klockars' students had observed in the United States, as 'the people who drive police cars'). ${ }^{2}$ For most police scholars in the 1960s and 1970s, 'policing' was simply what the (public) police do. Policing scholarship thus focused on discussions about the changing roles and practices of public police during those decades (for instance, the emergence at that time of a 'new' philosophy of 'community(-based) policing'?3).

Research and writing on 'private security' and 'private police' began to appear in the United States in the 1930s, ${ }^{4}$ and there were occasional articles published in the 1940s, 1950s and 1960 s. $^{5}$ But it was not until the $1970 \mathrm{~s}^{6}$ and $1980 \mathrm{~s}^{7}$ that this literature began to proliferate in

\footnotetext{
${ }^{2}$ Carl Klockar, The Idea of Police (Sage Publications 1985) 8.

${ }^{3}$ Actually, the idea of community policing was far from new; it had been advocated by police leaders such as August Vollmer in the United States as long ago as the second decade of the twentieth century (see R Fosdick, American Police Systems (The Century Co. 1920) 373; A Vollmer, The Police and Modern Society (University of California Press 1936) 214-215), and it was at least implied in the idea attributed to Sir Robert Peel by Charles Reith that the police are the public and the public are the police'; (see Ian Loader, 'In Search of Civic Policing: Recasting the "Peelian" Principles' (2016) 10(3) Criminal Law and Philosophy 427).

${ }^{4}$ For example, Allan Pinkerton, founder of the Pinkerton Detective Agency, published two books about his detectives in 1878 and 1881 respectively (see A Pinkerton, Strikers, Communists, Tramps and Detectives (first published G. W. Carlton \& Co. 1878, reprinted in 'Mass Violence in America Series' Arno Press); and A Pinkerton, Professional Thieves and the Detective (first published 1881, reprinted in 'Foundations of Criminal Justice Series', AMS Press Inc. 1933). See also J Shalloo, Private Police, with Special Reference to Pennsylvania (first published 1933, reprinted in 'Criminology, Law Enforcement and Social Problems Series, 199, Patterson Smith 1973); Anon, 'Industrial Strikebreaking - The Byrnes Act' (1936-37) 4 University of Chicago Law Review 657; United States Senate, Committee on Education and Labor, Private Police Systems (Lafollette Hearings, 1939); H Cooper, Fifteen Years A Store Detective (Pallas Publishing Co. 1940).

${ }^{5}$ For example, New York State Legislature, Committee on Privacy of Communications and Licensure of Private Detectives, Reports (New York State Legislature 1957 \& 1958); E Lodge, 'Regulation of Private Police'(1967) 40(3) Southern California Law Review 540; J Horan, The Pinkertons: The Detective Dynasty That Made History (Crown Publishers Inc. 1967); N Currer-Briggs (ed.) Security: Attitudes and Techniques for Management (Hutchinson 1968); R Momboisse, Industrial Security for Strikes, Riots and Disasters (Charles Thomas 1968); J Thurston, 'The Authority and Powers of Security Officers' (Unpublished paper delivered at the annual Crime in Industry seminar, Hamilton, Ontario, 1969).

${ }^{6}$ For example, M Braun and D Lee, 'Private Police Forces: Legal Powers and Limitations' (1971) 38(3) University of Chicago Law Review 555; J Kakalik and S Wildhorn, Private Police in the United States (5 vols, Rand Corporation 1971-72); T Scott and M McPherson, 'The Development of the Private Sector of the Criminal Justice System' (1971) 6(2) Law and Society Review 26; F McClintock and P Wiles (eds), The Security Industry in the United Kingdom (Institute of Criminology, University of Cambridge 1972); D Paine, Industrial Security (Oak Security, Publications Division 1972); S Pleece, 'The Nature and Potential of the Security Industry' (1972) XLIV(1) Police Journal 46; S Steinberg, 'Private Police Practices and Problems' (1972) 4 Law and the Social Order 585; Anon., 'Neighbourhood Patrols and the Law: Citizens' Responses to Urban Crime - Comment' (1973) 41(3) Fordham Law Review 973; T Becker, 'The Place of Private Police in Society: An Area of Research for the Social
} 
North America and somewhat later in the UK. From the titles of these publications, even going back to the 1930s, it can be seen that there was disagreement about whether private sector policing providers should be referred to as 'private security' or 'private police'. Interestingly, it seems that private security and public police leaders were pretty much in agreement about this, discouraging the term 'private police' - the public police because they thought the term 'police' should be used exclusively to refer to them, while private security executives were concerned (rightly, as it turned out) that the use of the term 'private police' was more likely to generate calls for government regulation of their industry. ${ }^{8}$ When government regulation did come, in the 1970s in North America and only 20 years later in the UK, two of its typical provisions were a ban on private security officers wearing 'police-like' uniforms, and the inclusion of an offence of impersonating a police officer. ${ }^{9}$

After some initial resistance in the 1970s, which has persisted among public police leaders, a gradual consensus began to emerge in the literature that, whatever they were called 'private security' or 'private police' - these non-state personnel and agencies could legitimately

Sciences' (1974) 21(3) Social Problems 438; D Williams, 'Crime Prevention and Private Security: Problems of Control and Responsibility'(1974) 48 Australian Law Journal 381; P Stenning and M Cornish, The Legal Regulation and Control of Private Policing in Canada (Centre of Criminology, University of Toronto1975); D Freedman and P Stenning, Private Security, Police and the Law (Centre of Criminology, University of Toronto1977); S Spitzer and A Scull, 'Privatization and capitalist development: the case of the private police' (1977) 25(1) Social Problems 18; H Draper, Private Police (Penguin Books/Pelican1978).

${ }^{7}$ For example, A Bilek, J Klotter and R Federal, Legal Aspects of Private Security (Anderson Publishing Co. 1980); C Shearing and P Stenning, 'The Quiet Revolution: The Nature, Development and General Legal Implications of Private Security in Canada' (1980) 22 (Canadian) Criminal Law Quarterly 220; C Shearing and P Stenning, 'Modern private security: its growth and implications' in M Tonry and N Morris (eds), Crime and Justice - An Annual Review of Research, vol. III, 193-245 (University of Chicago Press 1981); A Rees (ed.), Policing and Private Security (Australian Institute of Criminology 1983); C Shearing and P Stenning (eds), Private Policing (Sage 1987).

${ }^{8}$ C Shearing, P Stenning and S Addario, 'Corporate Perceptions of Private Security' (1985) 9(4) Canadian Police College Journal 367; C Shearing, P Stenning and S Addario, 'Police Perceptions of Private Security' (1985) 9(2) Canadian Police College Journal 127.

${ }^{9}$ See e.g. Stenning and Cornish (note 6 above) Ch. 6; B George \& M Button, 2000, Private Security (Palgrave, 2000); M Button and T John, "Plural policing" in action: A Review of the Policing of Environmental Protests in England and Wales' (2002) 12(2) Policing \& Society 111. 
be said to be doing 'policing'. By the turn of the century, there was little dispute about this. As

Stenning wrote in 2000, although their legal authority and powers differed,

...it is now almost impossible to identify any function or responsibility of the public police which is not, somewhere and under some circumstances, assumed and performed by private police in democratic societies. Policing policy-makers are nowadays resigned to the fact that any effective policing is likely to require some combination, collaboration or "networking" between public and private providers, and that the lines between the responsibilities of these various providers are likely to be difficult, if not impossible, to clearly demarcate. ${ }^{10}$

This consensus signalled an important shift in the literature on policing; no longer could 'policing' be defined just as 'what the (public) police do'. From here on, as the quote from Robert Reiner at the beginning of this chapter suggests, 'policing' came to be recognized as a social function, activity or service, which is in practice provided by all kinds of state and nonstate agents and organizations. Concern that the association of the term 'policing' with the public police, law enforcement and the criminal justice system had become too entrenched to be easily dislodged from academic and policy discourse eventually led some to prefer the term 'governance of security'. 11

\section{WHO CAN LEGITIMATELY BE THOUGHT OF AS 'POLICING PROVIDERS'?}

Our answer to this question has been partly, but not completely, provided in our discussion of what 'policing' is. Contributing to the conceptual shift we have discussed were critiques of much of the earlier private security literature. There were two strands to these critiques. The first was criticism of its almost exclusive focus on contract security companies - i.e. companies such as G4S, Pinkertons, Wackenhut, Brinks, etc., that provide security services and equipment to clients under contract - as if these companies alone constituted 'private security'. With some notable

\footnotetext{
10 Stenning, P, 'Powers and Accountability of Private Police' (2000) 8 European Journal on Criminal Policy and Research 325, 328.

${ }^{11}$ L Johnston and C Shearing, Governing Security: Explorations in Policing and Justice (Routledge 2003). As T S Eliot famously wrote in his poem Little Gidding: 'For last year's words belong to last year's language. And next year's words await another language' (II 65-6 Four Quartets 1942).
} 
exceptions, ${ }^{12}$ almost no attention was paid to the growing number of 'in-house' security

organizations - that is, security departments of large, often transnational, corporations (such as manufacturing, resource extraction, airline, shipping, hotel, banks and insurance companies) as well as of other institutions (such as hospitals, universities, sports stadia, museums and governments) whose role is exclusively to serve the security needs of the corporations and institutions that employ them. The second was criticism of the tendency to discuss private security as if its practitioners were simply private versions of public police officers, focused almost exclusively on crime, law enforcement and taking cases through the criminal justice system. Research on private security disclosed early on, however, that this is not the case private security tends most often, though not always, ${ }^{13}$ to have a broader focus on loss prevention rather than crime prevention, and frequently avoids interaction with the criminal justice system, in favour of informal 'private justice' responses that better reflect the interests of those for whom they work. ${ }^{14}$ Scholars became a bit preoccupied with the question as to whether the public police had now become outnumbered by private security personnel, signalling a possible shift from 'public interest policing' to private interest policing. ${ }^{15}$

These shifts in thinking about 'policing' and policing provision led, in the 1990s and early 2000s, to two important conceptual shifts. The first derived from the recognition that

\footnotetext{
${ }^{12}$ For example, F Jeffries, Private Policing: An Examination of In-House Security Operations (Centre of Criminology, University of Toronto1977); P Stenning and C Shearing, 'Corporate Security: Some Preliminary Thoughts' (1984) 17(2) Australian and New Zealand Journal of Criminology 79; R Weiss, 'From "Slugging Detectives" to "Labor Relations": Policing Labor at Ford, 1930-1947' in C Shearing and P Stenning (eds), Private Policing 110-130 (Sage 1987).

${ }^{13}$ G Rigakos, The New Parapolice: Risk Markets and Commodified Social Control (University of Toronto Press 2002).

${ }^{14}$ See e.g. S Henry, 'Private Justice and the Policing of Labor: The Dialectics of Industrial Discipline' in C Shearing and P Stenning (eds), Private Policing 45-71 (Sage 1987); C Shearing and P Stenning, Private Security and Private Justice: The Challenge of the 80's (The Institute for Research on Public Policy 1982).

${ }^{15}$ M Nalla and G Newman, 'Public versus private control: a reassessment' (1991) 19(6) Journal of Criminal Justice 537; and see more recent discussions of this by R Van Steden and R Sarre, 'The Growth of Privatized Policing: Some Cross-national Data and Comparisons' (2007) 31(1) International Journal of Comparative and Applied Criminal Justice 51; and J-P Brodeur, The Policing Web (Oxford University Press 2010).
} 
policing is not just provided by public police and private security/police, but by a whole host of other state and non-state personnel and agencies, a fact that was recognized later in the idea of 'nodal governance'. ${ }^{16}$ The second derived from a recognition that policing can be effected through a variety of institutional processes and arrangements that do not necessarily involve a specialized public or private agency. In particular, policing provision can be 'embedded' in other functions and occupations that do not have policing as their primary focus. Perhaps the earliest, and eventually most influential expression of this latter argument, was an article that we wrote about the policing of Disney World in Florida, that grew out of a visit by Shearing and his daughter in 1983, and applied Foucaultian ideas of 'discipline' to the topic. ${ }^{17}$ It was not until the first decade of the 2000s, however, that the term 'plural policing' appeared regularly in the policing lexicon, to encapsulate these two conceptual shifts. ${ }^{18}$

By the beginning of the 2000s, there was a recognition that a revised definition of 'policing' was needed that would take into account contemporary realities and insights. In 2005, Crawford and his colleagues at Leeds University obliged:

For our purposes "policing" is defined as intentional action involving the conscious exercise of power or authority (by an individual or organisation) that is directed towards rule enforcement, the promotion of order or assurances of safety. ${ }^{19}$

\footnotetext{
${ }^{16}$ For a review, see C Holley and C Shearing, 'A Nodal Perspective of Governance: Advances in Nodal Governance Thinking' in P Drahos (ed.), Regulatory Theory: Foundations and Applications 163-180 (Australian National University Press 2017).

${ }^{17}$ C Shearing and P Stenning, 'From the Panopticon to Disney World: The Development of Discipline' in A Doob and E Greenspan (eds), Perspectives in Criminal Law 335-349 (Canada Law Book Co. 1984).

${ }^{18}$ See in particular I Loader, 'Plural Policing and Democratic Governance' (2000) 9(3) Social \& Legal Studies 323; Button and John (note 8 above); Johnston and Shearing (note 10 above); T Jones and T Newburn (eds), Plural Policing: A Comparative Perspective (Routledge 2006); A Crawford, 'Plural policing in the UK: policing beyond the police' in T Newburn (ed), Handbook of Policing 147-181 (2 $2^{\text {nd }}$ edn, Routledge 2008).

${ }^{19}$ Crawford et al. (note 18 above) 4.
} 
We recognized ${ }^{20}$ that this definition has several features that were particularly helpful for understanding the realities of policing in the early twenty-first century:

1. Neither the state nor the public police are specifically mentioned in it.

2. None of the words 'crime', 'law' or 'criminal justice' appear in it.

3. The definition does not suggest that policing is necessarily something that is only undertaken within a specified geographical territory.

4. It refers to 'power' as well as 'authority' as a basis for policing.

5. It notes that policing does not necessarily have to be done by an 'individual'.

6. It defines policing as involving an intentional and conscious exercise of power or authority specifically directed to the achievement of particular ends.

7. Despite these previous six features, the definition easily covers what the public police do.

Despite, or perhaps rather because of these advantages of Crawford et al.'s definition, it poses some significant challenges for deciding how modern-day policing may be effectively governed. One of these is that it dramatically enlarges the categories of people who and organizations that can legitimately be regarded as 'providers of policing'. Our 'Disney World' article, ${ }^{21}$ for instance, illustrated how policing in this theme park was being provided by people dressed up as Disney characters (Mickey Mouse and Goofy, for instance). In other work we have illustrated how this embedding of policing work in occupations for which policing is not the principal activity, results in policing being provided by such people as retail store cashiers, subway employees, school teachers, and lots of others. Indeed, conventional understandings of 'community-based policing' recognise that policing provision typically requires the involvement of ordinary citizens, as policing is not a function that can be effectively provided 'by the (public) police alone'. In recent times, politicians and policy-makers have recognized that even what

\footnotetext{
${ }^{20} \mathrm{P}$ Stenning and C Shearing, 'The shifting boundaries of policing: globalization and its possibilities' in T Newburn and J Peay (eds), Policing: Politics, Culture and Control 265-284 (Hart Publishing 2012) 268.

${ }^{21}$ Shearing and Stenning (note 17 above).
} 
Brodeur regarded as 'high policing' ${ }^{22}$ - that is, policing against threats, including insurgency and terrorism, against the state and its system of government - requires community input to be effective. ${ }^{23}$ This realization - that virtually anybody can make a significant contribution to policing provision - has become even more salient in recent times as a result of technological developments such as the internet, mobile phones, drones and various tracking devices, which have given rise to what Mann et al. referred to as 'sousveillance'24 - developments which have given 'private policing' a whole new meaning, and police accountability a whole new dimension. ${ }^{25}$ Other challenges for the governance of policing that arise from such a broad definition of 'policing' are discussed further below.

\section{HOW, AND BY WHOM, SHOULD POLICING BE GOVERNED IN AN ERA OF PLURAL PROVISION, INVOLVING NON-STATE AS WELL AS STATE PROVIDERS?}

Despite the fact that these new understandings of 'policing' have been around for at least 20 years, thinking about, and certainly practices of, the governance of policing, have not kept pace. To this day, arrangements for the governance of policing still reflect a conventional view that policing is defined as what public and private police/security personnel and organisations do. So the governance of policing consists of separate and different legislative regimes, principles and institutional arrangements for the public police ${ }^{26}$ and private security, ${ }^{27}$ the latter, in many if not most jurisdictions, being regulated by the former. These legislative regimes are based on the

\footnotetext{
${ }^{22}$ J-P Brodeur, 'High policing and low policing: remarks about the policing of political activities' (1983) 30(5) Social problems 507.

${ }^{23} \mathrm{~J}$ Klausen, 'British Counter-Terrorism after 7/7: Adapting Community Policing to the Fight Against Domestic Terrorism' (2009) 35(3) Journal of Ethnic and Migration Studies 403.

${ }^{24}$ S Mann, J Fung and R Lo, 'Cyborglogging with camera phones: steps toward equiveillance' in Proceedings of the 14th ACM International Conference on Multimedia 177-180 (ACM 2006).

25 A Goldsmith, 'Policing's New Visibility' (2010) 50(5) British Journal of Criminology 914

${ }^{26}$ D Bayley and P Stenning, Governance of the Police: Experience in Six Democracies (Transaction Publishers 2016).

${ }^{27}$ Prenzler, T and R Sarre, 'Regulation' in M Gill (ed.), The Handbook of Security 857-878 (Palgrave Macmillan 2014).
} 
assumption that regulation by domestic government institutions is the only conceivable, viable governance option. This does not take into account the modern plurality of policing provision, the globalization and privatization of its provision, and the fact that much of it occurs in the nonterrestrial domain of the Internet, which is not easily subjected to state government regulation (see contribution Munk infra). Loader, however, was expressing accepted wisdom when he wrote, in 2000, that 'It is hard to envisage any agency other than the state with the capacity to undertake' the regulation of plural policing provision' ${ }^{28}$

During the last 20 years, however, ideas about how plural policing provision might be effectively governed have been canvassed by a number of policing scholars in North America and the UK. We, and others (see below), began to think seriously about this from the mid-1990s. In 1997 Stenning gave a presentation to Metropolitan Toronto's Anti-Racism, Access and Equity Committee, at a meeting held to discuss police governance arrangements in the city. He put forward a tentative suggestion for the establishment of a new policing governance institution, to complement the existing Police Services Board, which would have a mandate to oversee and coordinate the activities of all state and non-state policing providers in the city. Quoted here in full are the six reforms that were recommended:

1. Establish a Safety and Security Committee for the city which would have overall responsibility for the provision of effective policing (as opposed to just police services) for the city and would be accountable to City Council. Broad community representation on, and input into the work of, this committee should be actively encouraged so that a lively, on-going and inclusive public dialogue about objectives, priorities and policy for effective community policing for the city will occur.

2. Establish and support more local community or neighbourhood safety and security committees with a mandate to focus on more local issues, to act as resources and local liaison for the central Safety and Security Committee,

\footnotetext{
${ }^{28}$ Loader (note 18 above).
} 
and to help co-ordinate the provision of effective policing services at the more local level.

3. Develop, and keep updated, a full inventory of potential resources for the provision of policing services within the community other than the police force. This might include, for example, Metropolitan Toronto Housing Authority security, the Toronto Transit Commission, taxi drivers (the 'TOPS' program), in-house and contract private security, school authorities, universities and colleges, community and neighbourhood security and policing programs, etc. etc. Once one begins to think of policing, safety and security in these terms, the list becomes almost endless.

4. Develop an annual policing plan for the city after extensive community consultation through the Safety and Security Committee and the more local community/neighbourhood committees. Ensure that the plan includes clear and achievable objectives, and that the extent to which these objectives have been met will subsequently be publicly discussed and evaluated.

5. Establish a policing budget for the city which would be allocated to ensure the provision of the most effective policing services for the city. Insist that the police force (and the police services board) must justify its budgetary claims (i.e. the police budget) within the priorities of the broader policing budget - i.e. the police force will be competing with other potential public, private and community providers of policing services for allocation of resources from the policing budget. Such resources will only be allocated to the police force (or any other potential provider of policing services) if, and to the extent that, it can satisfy the community that such allocation would represent the best use of such funds. Encourage other potential providers of policing services to apply for funding from this policing budget.

6. Appoint as the city's representatives on the police services board (whose main responsibility is to govern the police force) persons who understand, are sympathetic to, will co-operate with, and will encourage the police force and the police services board as a whole to co-operate with, this broader agenda for securing effective policing for the city. Some members of the police services board could perhaps also serve on the Safety and Security Committee, but should not be allowed to dominate it. (Emphases in the original). ${ }^{29}$

${ }^{29}$ P Stenning, 'Reclaiming the Policing Agenda - A Proposal for Change'. Unpublished presentation to the Metropolitan Toronto Anti-Racism, Access and Equity Committee, 11September 1997, 4-5 (copy available from the author). 
This proposal was not taken up or acted upon by the city authorities, perhaps because the committee to which these ideas were presented was primarily concerned with issues of racism and equity, rather than police governance more generally.

The following year, the Independent Commission on Policing for Northern Ireland (commonly known as the Patten Inquiry, after its Chairman, The Rt. Hon. Christopher Patten, $\mathrm{CH}$ ), which had been set up pursuant to the Belfast Agreement of April 1998, published its report. ${ }^{30}$ Shearing was a member of the Commission. The Agreement had included a call for 'a new beginning to policing in Northern Ireland with a police service capable of attracting and sustaining support from the community as a whole'. ${ }^{31}$ Despite this conventional association between 'policing' and a public 'police service', the chapter (Chapter 6) of the Commission's report that addressed issues of police governance and democratic accountability reflected the broad approach to 'policing' that we had discussed in Toronto. The Commission recommended the establishment of a new 'Policing Board' for Northern Ireland, to replace the existing Police Authority (the governing authority for the Royal Ulster Constabulary). While it recommended that 'the statutory primary function of the Policing Board should be to hold the Chief Constable and the police service publicly to account,${ }^{32}$ it also wrote:

The title 'Policing Board' is deliberate. We see the role of the new body going beyond supervision of the police service itself, extending to the wider issues of policing and the contributions that people and organizations other than the police can make towards public safety. We recommend that the Policing Board should coordinate its work closely with other agencies whose work touches on public safety, including education, environment, economic development, housing and health authorities, as well as social services, youth services and the probation service, and with appropriate non-governmental organizations. (Emphasis in original). ${ }^{33}$

\footnotetext{
${ }^{30}$ Independent Commission on Policing for Northern Ireland, A New Beginning: Policing in Northern Ireland (H.M.S.O. 1999).

${ }^{31}$ Ibid 4.

${ }^{32}$ Ibid 28.

${ }^{33}$ Ibid 29.
} 
The Commission also recommended the establishment of District Policing Partnership Boards (DPPBs), as committees of the District Councils throughout the Province, with a majority elected membership. The DPPBs "should be encouraged to see policing in its widest sense, involving and consulting non-governmental organisations and community groups concerned with safety issues as well as statutory agencies." 34

The most radical of the Commission's recommendations, however, was its recommendation that the Policing Board should be responsible for negotiating an 'annual policing budget' (our emphasis) with the government, a certain proportion of which would be allocated as the 'police service budget' (again our emphasis) of the new Police Service of Northern Ireland, the creation of which it had recommended. ${ }^{35}$ At the local level, District Councils should have the power to contribute funding towards the improved policing of the district, "which could enable the DPPB to purchase additional services from the police or other statutory agencies, or from the private sector" (our emphasis) ${ }^{36}$ At that time, private security services were not subject to statutory regulation in Northern Ireland. The Commission recommended that should they be subject to such regulation in the future, the new Policing Board should be the regulatory authority.

Many of these recommendations of the Commission, including recommendations for the establishment of the new Police Service of Northern Ireland, the new Policing Board and DPPBs, were subsequently adopted in the Province. The important recommendation to allow for additional local funding from District Councils, however, was not adopted. ${ }^{37}$

\footnotetext{
${ }^{34}$ Ibid 35.

${ }^{35}$ Ibid 28.

${ }^{36}$ Ibid 35.

${ }^{37}$ B Ryan, Northern Ireland's District Policing Partnerships and the Participatory Ideals' (2008) 23(3) Irish Political Studies 341.
} 
Loader, then at Keele University, had also been applying his mind to these issues, and in 2000 published an article entitled 'Plural Policing and Democratic Governance'. ${ }^{38}$ In it, he proposed new governance arrangements for plural policing in Britain that were somewhat similar to those that had been recommended by the Patten Inquiry for Northern Ireland. In introducing his proposals, Loader wrote:

In the wake of an increasingly widespread realization that plural policing is here to stay, these questions have begun to receive some attention of late. It has been argued, in particular, that if diverse policing networks are to avoid 'compounding' extant inequities, then institutional means have to be found of connecting such networks to the 'public' or 'common good'. ${ }^{39}$

After reviewing and critiquing some other recent proposals for reform of police governance and regulation of private security that had been canvased in the UK, Loader wrote:

In broad outline and intent these proposals retain a fair degree of merit as a means of rendering the police democratically accountable. However, against the backdrop of plural, networked policing set out in this article, it has I believe become more fruitful to think about the creation of national, regional and local policing commissions, institutions whose (revised) purpose would be to formulate policies and coordinate service delivery across the policing network, and to bring to democratic account the public, municipal, commercial and voluntary agencies that comprise it. ${ }^{40}$

Loader argued that these policing commissions should have a number of key functions, not dissimilar to those that the Patten Inquiry had recommended for the Northern Ireland Policing Board: (1) policy formulation and strategic co-ordination, through the development and promulgation of policing plans to guide the activities and priorities of all the plural policing providers; (2) regulating the private security industry; (3) 'inviting tenders

\footnotetext{
${ }^{38}$ Loader (note 18 above).

${ }^{39}$ Loader (note 18 above) 335. This issue of the public or common goods and policing is an issue that Ian Loader, both alone and with collaborators, has since explored in some depth, for example in, among others, I Loader, 'Plural Policing and Democratic Governance' (2000) 9(3) Social \& Legal Studies 323; I Loader and N Walker, Civilizing Security (Cambridge University Press 2007); I Loader and A White, 'How Can We Better Align Private Security with the Public Interest? (2017) 11, Regulation \& Governance 166. See also Ryan (note 37 above).

${ }^{40}$ Loader (note 18 above) 337.
} 
from, and issuing contracts to, public, municipal, commercial or voluntary agencies who might wish to provide services required under a policing plan'; (4) 'using their powers to make good inequities in the (local) provision of policing and security, something that may involve commissions in either allocating state police resources in particular ways or using their funds to 'buy in' services for disadvantaged communities'; (5) 'bringing the constituent nodes of the policing network to democratic account' through monitoring, inspection and evaluation. ${ }^{41}$

By the beginning of the twenty-first century, therefore, a broad consensus seemed to be emerging in Canada and the UK as to what kinds of institutional governance arrangements might be suitable for effective governance of domestic plural policing environments. ${ }^{42}$ This was an important development in thinking about policing and the governance of plural policing. But all of these recommendations for governance of policing still reflected a view of policing in which the public police, the domestic state, crime control and law enforcement were represented as the core of 'policing', with all other policing providers portrayed as merely contributing to, or assisting the public police, in performing this core function in various ways, and often portrayed as providing ancillary 'security' functions, rather than 'policing' as such. In line with this view, the governance models for plural policing that had been canvassed in Canada and the UK had all been based on the assumption that governments of nation states were the only conceivable and appropriate providers of such governance, albeit with some devolution to local governments.

This view of 'policing' did not take into account either the burgeoning development of transnational plural policing that had been spawned by the late twentieth century/early twenty-

\footnotetext{
${ }^{41}$ Loader (note 18 above) 339-340.

${ }^{42}$ See P Stenning, 'Governance and Accountability in a Plural Policing Environment - The Story So Far' (2009) 3(1) Policing - A Journal of Policy and Practice 22.
} 
first century phenomenon of 'globalisation' ${ }^{43}$ or the fact that, pursuant to technological developments (Manning, infra), an increasing volume of policing was occurring in the nonterrestrial, transnational cybersphere (Munk, infra). ${ }^{44}$ It will be obvious that a governance model that sees the nation state as the only viable instrument of governance for plural policing cannot easily be applied to the governance of transnational terrestrial plural policing, let alone of policing in the cybersphere; there is no transnational or international equivalent of a national government. Although the United Nations is probably the closest thing to an international government, it certainly does not have a mandate, the capacity, authority or (in the eyes of some) legitimacy to govern transnational, international and virtual communities comparable to that of long established and entrenched national governments with respect to their domestic societies. In considering viable governance arrangements for transnational plural policing (Egan, infra), therefore, some more creative and less state-centred thinking is required.

In 2010, Johnston and Stenning addressed the challenges of governing transnational private policing. Taking the governance of transnational commercial security (TCS) as its reference point, the article illustrated the great complexity and diversity of the TCS market, in terms of the types of companies involved, the varieties of their roles and functions, relationships between the countries in which they operate and those where their headquarters are based, and between them and their (typically government and corporate) clients, the status and citizenship of their employees, and the variety of legal regimes (including international humanitarian law and

\footnotetext{
${ }^{43}$ See e.g. J Sheptycki (ed.), Issues in Transnational Policing (Routledge 2000); R Abrahamsen and M Williams, Security Beyond the State: Private Security in International Politics (Cambridge University Press 2011); B Bowling and J Sheptycki, Global Policing (Sage Publications 2012).

${ }^{44}$ L Huey, J Nhan and R Broll, "Uppity civilians" and "cyber-vigilantes": The role of the general public in policing cybercrime' (2013) 13(1) Criminology \& Criminal Justice 81; D Wall and M Williams, 'Policing cybercrime: networked and social media technologies and the challenges for policing' (2013) 23(4) Policing and Society 409; B. Dupont, 'Bots, cops and corporations: On the limits of enforcement and the promise of polycentric regulation as a way to control large-scale cybercrime'(2017) 67 (1) Crime, Law and Social Change 97.
} 
sometime laws of war) under which they operate. The result of this complexity, it was argued, is that attempts to govern and hold TCS accountable typically involves a 'tangled web' of confusing and often inconsistent 'multiplex' governance arrangements, involving state, private and international non-government advocacy groups. The authors concluded:

This analysis suggests that once security ceases to be the exclusive prerogative of the state and becomes, instead, the product of multiple auspices and providers, the limits of conventional ('Westphalian') solutions to security governance are exposed. Despite this, debate about the governance and accountability of TCS remains dominated by formal-legal discourse. According to this, 'good governance' is the product of formal-legal interventions by states, either individually or in collaboration with one another. Undoubtedly, legal intervention does have a vital role to play in governance. Yet, it also has limitations. ${ }^{45}$

They argued that pluralized security inherently requires pluralized modes of governance and accountability, and that this is especially the case in the transnational sphere. Referencing Cockayne's discussion ${ }^{46}$ of the 2009 Montreux Document ${ }^{47}$ and Caparini ${ }^{48}$ they concluded:

Under such multiplex regimes, many different actors would be required to play a governance role including state bodies, professional associations, industry associations, accreditation bodies, labour unions, banks and other businesses, insurance companies, NGOs, and international organizations, such as the IMF, the World Bank and the EU.... Their role would be to offer a plurality of interventions in respect of governance: from compliance and standard-setting to the

\footnotetext{
${ }^{45}$ Johnston, L and P Stenning, 'Challenges of governance and accountability for transnational private policing' in F Lemieux (ed.), International Police Co-operation: Emerging issues, theory and practice 281-297 (Willan Publishing 2010) 294.

${ }^{46}$ J Cockayne, 'Regulating Private Military and Security Companies: The Content, Negotiation, Weaknesses and Promise of the Montreux Document' (2008) 13(3) Journal of Conflict and Security Law 401.

${ }^{47}$ International Committee of the Red Cross and Department of Foreign Affairs, Switzerland, The Montreux Document On pertinent international legal obligations and good practices for States related to operations of private military and security companies (ICRC \& Switzerland Department of Foreign Affairs 2009) $<$ https://www.icrc.org/eng/assets/files/other/icrc 002_0996.pdf $>$. The Montreux Document was drawn up by the Swiss government in collaboration with the International Committee of the Red Cross. The title page states that it explored 'pertinent international legal obligations and good practices for States related to operations of private military and security companies during armed conflict'. It proposed standards for Private Military and Security Companies (PMSC's) when operating in conflict situations. It led to the establishment of the International Code of Conduct Association (ICoCA), which, at the time of writing, has a voluntary membership of seven governments, 100 private contract security companies from many countries of the world, and 18 civil society organizations, and has promulgated an international Code of Conduct for Private Security Providers (ICoC); see $<$ http://www.icoca.ch/en/icoc-association>.

${ }^{48}$ Caparini, M, 'Regulating private military and security companies: The US approach' in A. Alexandra, D-P Baker \& M Caparini (eds), Private military and security companies: Ethics, policies and civilmilitary relations 171-188 (Routledge 2008).
} 
inculcation of professional norms; and from the application of formal-legal rules to the development of self-regulatory regimes. ${ }^{49}$

It seems obvious that if this is the kind of recipe that is required for the governance of transnational commercial security, it will a fortiori be required for international and transnational plural policing more generally. And it raises questions about earlier suggestions that the state is the only plausible agency with the capacity and legitimacy to govern plural policing even at the domestic level, let alone in the transnational sphere.

To the mix of governance participants suggested by Cockayne ${ }^{50}$ and Johnston and Stenning ${ }^{51}$ might be added new participants whose role in governance has been introduced through the recent emergence of the so-called 'disruption economy', ${ }^{52}$ and facilitated by new technology and social media. New disruptive market innovators, such as Airbnb and Uber, enrol their customers and operatives in the process of governance. In a model of ground-up accountability, customers of Uber's 'ride-share' services, for instance, are invited to submit reports on their drivers, and drivers to submit reports on their customers, to the company. The reports are used as data in performance evaluations of customers and drivers alike; misconduct by either party may lead to warnings or, if persistent, their exclusion from the service. A similar system of mutual accountability through customers and hosts applies to governance in Airbnb. With respect to governance and accountability of public police, the development of the 'Five-O' app by three high school students from the state of Georgia, USA, in $2015,{ }^{53}$ offers another

\footnotetext{
49 Johnston and Stenning (note 45 above) 296.

${ }^{50}$ Cockayne (note 46 above.)

${ }^{51}$ Johnston and Stenning (note 45 above).

${ }^{52}$ M Ingram, 'Airbnb, Coursera, and Uber: The rise of the disruption economy' Bloomberg Businessweek (25 October 2012) < https:/www.bloomberg.com/news/articles/2012-10-25/airbnb-coursera-and-uber-the-rise-of-thedisruption-economy>.

${ }^{53}$ The Economist (2 January 2016, p. 25) 'Rating police officers: how one family of high school students is policing the cops" < http://www.economist.com/news/united-states/21684818-how-one-family-high-school-studentspolicing-cops-revenge-nerds $>$.
} 
example of such social media-based, ground-up, 'client'-based involvement in governance that could potentially be adopted in a governance regime for plural policing.

In line with these suggestions that effective governance of plural policing requires plural or 'multiplex' governance models, the idea of 'nodal governance' of policing, advanced by Shearing and his colleagues,${ }^{54}$ has been another important contribution to the debate. Its proponents argue that a nodal governance conception, in which the public/state police and the state itself are 'de-centred' while still being acknowledged as critical players in plural policing provision, is not just a theoretical construct, but truly reflects the largely unexplored reality of plural policing in the twenty-first century. Recognition of recent debates about governance of the Internet is no less important in this respect. ${ }^{55}$

To summarize these developments, it is clear that the reality of plural policing, both domestically and transnationally, and the challenges that it poses for effective governance, accountability and legitimacy, have entered the consciousness of policing scholars and policymakers gradually over the last twenty years or so. While there have been several suggestions as to the possible architecture of a model of governance for plural policing, no such models have yet got far beyond the intellectual and aspirational drawing board anywhere in the world. We turn now, therefore, to a consideration of what might be appropriate principles for the design of such governance models.

\section{WHAT PRINCIPLES SHOULD UNDERPIN THE GOVERNANCE OF PLURAL POLICING?}

While there has been a growing literature on the emergence of plural policing in the last three decades, not much of it has focused on the principles that should underpin such governance. In

\footnotetext{
${ }^{54}$ Shearing, C and J Wood, 'Nodal governance, democracy and the new "denizens"' (2003) 303(3) Journal of Law and Society 400; Johnston and Shearing (note 11 above); Holley and Shearing (note 16 above).

${ }^{55}$ K Raustiala, 'Governing the Internet' (2016) 110(3) The American Journal of International Law 491.
} 
2000, however, Ian Loader, in addition to recommending a governance structure for plural

policing in the UK, as summarized above, argued that

[i]f policing commissions are to fulfil their remit in ways that sustain considerations of democratic deliberation, equity and effectiveness in the delivery of policing and security services, they would need, I believe, to be guided by $a$ principle of public justice that has been altered to encompass the following three dimensions. (Our emphasis). ${ }^{56}$

The three dimensions he recommended were:

1. A politics of recognition, that would 'require policing commissions to elicit and take account of the views of all individuals and social groups likely to be affected either by their decisions, or by the actions of any policing/security agency operating in spaces to which the public routinely have access (even if such spaces are privately owned).'

2. A politics of human rights, that would require policing commissions 'to arrive at decisions that secure the broadest levels of public agreement, without either: (1) prejudicing the active rights of any individual or social group affected by the decision; or (2) acting in ways that are disproportionately detrimental to the other interests and aspirations of such individuals and groups.'

3. A politics of allocation, that would require policing commissions 'to act in such a way as to ensure that all citizens were provided with a "fair" share of available policing resources, something that would entail them giving attention both to the unwarranted "over"- (or overly invasive) policing of particular individuals or social groups, and to the inability of (disadvantaged) citizens and communities to acquire from within the network a proportionate level of policing resources. ${ }^{57}$

On the basis of our own research on plural policing, and review of the extant literature, we would recommend the following key principles that should underpin the governance of plural policing, domestically and internationally. These build on, and add to, the principle of justice that Loader advocated:

1. Policing provision must be pursued with integrity - that is, without corruption or misrepresentation.

${ }^{56}$ Loader (note 18 above) 337

${ }^{57}$ Ibid (2000: 337-338) 
2. All the policing providers should be operating on a 'level playing field' - that is, that the same standards and similar regulation should apply equally to public providers and private sector providers.

3. Policing provision must be within the confines of the Rule of Law - not just domestic law, but international law as well, in the context of a globalized economy, as well as a transnational jurisdictional structure.

4. Policing provision must be human rights compliant, and non-discriminatory.

5. The safety and security of the general public and of policing employees - the policing workforce - must be the highest priority for all policing providers.

6. Collectively, the market must meet the public good needs for policing provision, by whatever combination of private and public provision will best meet this need. The legitimate public needs for policing must be met somehow.

7. The policing workforce, both public and private, must be treated fairly and not exploited.

8. All public policing provision, whether through the public or private sectors, must be democratically and legally accountable, including effective mechanisms for addressing complaints by those being policed.

9. Governance of plural policing must be through an independent body that is not beholden to the interests of one or more particular group of policing providers (including, of course, the public police) with an explicitly authorized mandate, and which reports on its oversight activities.

Several of these principles reflect our view that effective and honest policing can legitimately be considered to be a public good, in the sense that all members of the public have a common interest in, and entitlement to benefit from, its provision, to the extent at least that it is essential for the protection of basic human rights such as life, liberty and security of the person. ${ }^{58}$ That is not, however, to say that some policing may not legitimately be treated as serving 'club' $\operatorname{goods}^{59}$ when its provision only affects, and is only intended for, the benefit of, a particular

\footnotetext{
${ }^{58}$ M Ruteere, C Shearing and P Stenning, 'Human Rights and Pluralization of Policing' in L Weber, E Fishwick and M Marmo (eds), The Routledge International Handbook of Criminology and Human Rights 396-404 (: Routledge 2016).

${ }^{59} \mathrm{~T}$ Hope, 'Inequality and the clubbing of private security' in T Hope and R Sparks (eds), Crime, Risk and Insecurity 83-106 (Routledge 2000).
} 
segment of society (e.g. the staff and students of a university). Private governments ${ }^{60}$ are

entitled to make and enforce rules for the terrains they govern, so long as such rules and policing do not subvert, undermine or detract from the civil and human rights, the benefit of which every member of the public is entitled to enjoy. Such 'private policing' is legitimately a club good, rather than a public good. We recognize, of course, that such a distinction is easy to express in theory, but not always at all easy to apply in practice. In particular, its application to the policing of private property rights is notoriously controversial, especially when the private property concerned is 'mass private property', so commonly policed by private rather than public police. ${ }^{61}$ But that does not deny its legitimacy, and those who are charged with governing plural policing should recognise this in their governance arrangements and practices.

\section{CONCLUSION}

Policing today, as Brodeur ${ }^{62}$ has eloquently argued, constitutes a complex web of nodes - both 'auspices' and 'providers' of security ${ }^{63}$ - that engage each other in a variety of ways, sometimes contesting, sometimes co-operating and sometimes indifferent to each other. It is time, as Sparrow has argued, ${ }^{64}$ to accept nodal policing as the new norm, and as a central feature of twenty-first century policing landscapes. We need to develop ways of governing this landscape as an integrated whole. This is difficult enough as we look back over the shifting harm landscapes (Holley \& Shearing, 2017 ${ }^{65}$ ) that established forms of policing have sought to

\footnotetext{
${ }^{58}$ S Macaulay, 'Private Government' in L Lipson and S Wheeler (eds), Law and the Social Sciences 445-518 (Russell Sage Foundation1986).

${ }^{61}$ M Kempa, P Stenning and J Wood, 'Policing communal spaces: a reconfiguration of the Mass Private Property hypothesis' (2004) 44(4) British Journal of Criminology 562.

${ }^{62}$ Brodeur (note 15 above).

${ }^{63}$ D. Bayley and C. Shearing, 'The future of policing' (1996) Law and Society Review 585.

${ }^{64}$ M Sparrow, 'Managing the Boundary Between Public and Private Policing' in New Perspectives in Policing Bulletin (US Department of Justice, National Institute of Justice 2014).

${ }^{65}$ C. Holley C. Shearing "Thriving on a Pale Blue Dot: Criminology and the Anthropocene" in C. Holley and C. Shearing C. (eds.) Criminology and the Anthropocene. Abingdon, UK and New York, USA: Routledge, 2017.
} 
govern. It is, and will become, even more challenging as these landscapes shift, often literally under our feet, in fundamental ways as new harms/safety deficits, such as environmental harms, cyber harms, and, of course, the mass harms of terrorism, emerge as defining features of our contemporary world. The design principles we have articulated, and that others have, and are, articulating, will always be playing catch-up as policing changes in multiple ways - with respect to auspices, providers, technologies and practices - in response to these changing harm landscapes. As we have argued, acceptable, effective and legitimate models for the governance of plural policing in the twenty-first century are so far only in the early stage of legal development, nationally and transnationally.

\section{References}

Abrahamsen, R. and M Williams, Security Beyond the State: Private Security in International Politics (Cambridge University Press 2011).

Anon, 'Industrial Strikebreaking - The Byrnes Act' (1936-37) 4 University of Chicago Law Review 657.

Anon, 'Neighbourhood Patrols and the Law: Citizens' Responses to Urban Crime - Comment' (1973) 41(3) Fordham Law Review 973. Bayley, D. \& Shearing, C. 2001. The New Structure of Policing. (National Institute of Justice, U.S. Department of Justice, 2001).

Bayley, D. and C. Shearing, 'The future of policing' (1996) Law and Society Review 585-606.

Bayley, D. and P. Stenning, Governance of the Police: Experience in Six Democracies (Transaction Publishers 2016).

Becker, T, 'The Place of Private Police in Society: An Area of Research for the Social Sciences' (1974) 21(3) Social Problems 438 (1974) 438.

Bilek, A, J Klotter and R Federal, Legal Aspects of Private Security (Anderson Publishing Co. 1980).

Bowling, B, and J Sheptycki, Global Policing (Sage Publications 2012).

Braun, M, and D Lee, 'Private Police Forces: Legal Powers and Limitations' (1971) 38(3)

University of Chicago Law Review 555. 
Brodeur, J-P, 'High policing and low policing: remarks about the policing of political activities' (1983) 30(5) Social problems 507.

Brodeur, J.-P, The Policing Web (Oxford University Press 2010).

Button, M and T John, "Plural policing" in action: A Review of the Policing of Environmental Protests in England and Wales' (2002) 12(2) Policing \& Society 111.

Caparini, M, 'Regulating private military and security companies: The US approach'

in a Alexandra, D-P Baker \& M Caparini (eds), Private military and security companies: Ethics, policies and civil-military relations 171-188 (Routledge 2008).

Cockayne, J, 'Regulating Private Military and Security Companies: The Content, Negotiation, Weaknesses and Promise of the Montreux Document' (2008) 13(3) Journal of Conflict and Security Law 401.

Cooper, H, Fifteen Years A Store Detective (Pallas Publishing Co. 1940).

Crawford, A, 'Plural policing in the UK: policing beyond the police' in T Newburn (ed), Handbook of Policing 147-181 ( $2^{\text {nd }}$ edn, Routledge 2008).

Crawford, A, S Lister, S Blackburn and J Burnett, Plural Policing: The mixed economy of visible patrols in England and Wales (The Policy Press 2005).

Currer-Briggs, N (ed.), Security: Attitudes and Techniques for Management (Hutchinson 1968).

Draper, H, Private Police (Penguin Books/Pelican1978).

Dupont, B. 'Bots, Cops and Corporations : On the Limits of Enforcement and the Promise of Polycentric Regulation as a Way to Control Large-scale Cybercrime' (2017) 67 (1) Crime, Law and Social Change 97.

Fosdick, R, American Police Systems (The Century Co. 1920).

Freedman, D and P Stenning, Private Security, Police and the Law (Centre of Criminology, University of Toronto1977).

Goldsmith, A, 'Policing's New Visibility' (2010) 50(5) British Journal of Criminology 914.

Henry, S. 'Private Justice and the Policing of Labor: The Dialectics of Industrial Discipline' in C Shearing and P Stenning (eds), Private Policing 45-71 (Sage 1987).

Holley, C, and C Shearing, a 'A Nodal Perspective of Governance : Advances in Nodal Governance Thinking' in P Drahos (ed.), Regulatory Theory: Foundations and Applications 163-180 (Australian National University Press 2017). 
Holley, C. and Shearing, C., b 'Thriving on a Pale Blue Dot: Criminology and the Anthropocene" in Holley, C and Shearing C. (eds.) Criminology and the Anthropocene. (Abingdon, UK and New York, USA: Routledge, 2017).

Hope, T, 'Inequality and the clubbing of private security' in T Hope and R Sparks (eds), Crime, Risk and Insecurity 83-106 (Routledge 2000).

Horan, J, The Pinkertons: The Detective Dynasty That Made History (Crown Publishers Inc. 1967).

Huey, L, J Nhan and R Broll, "Uppity civilians" and "cyber-vigilantes": The role of the general public in policing cybercrime' (2013) 13(1) Criminology \& Criminal Justice 81.

Independent Commission on Policing for Northern Ireland, A New Beginning: Policing in Northern Ireland (H.M.S.O. 1999).

Ingram, M, 'Airbnb, Coursera, and Uber: The rise of the disruption economy' Bloomberg Businessweek (25 October 2012) < https://www.bloomberg.com/news/articles/2012-1025/airbnb-coursera-and-uber-the-rise-of-the-disruption-economy $>$.

International Code of Conduct Association (ICoCA), Code of Conduct for Private Security Providers (ICoC); see $<$ http://www.icoca.ch/en/icoc-association $>$.

International Committee of the Red Cross and Department of Foreign Affairs, Switzerland, The Montreux Document On pertinent international legal obligations and good practices for States related to operations of private military and security companies (ICRC \& Switzerland Department of Foreign Affairs 2009) $<$ https://www.icrc.org/eng/assets/files/other/icrc_002_0996.pdf .

Jeffries, F, Private Policing: An Examination of In-House Security Operations (Centre of Criminology, University of Toronto1977).

Johnston, L. (1992) The Rebirth of Private Policing (London/New York: Routledge).

Johnston, L and C Shearing, Governing Security: Explorations in Policing and Justice (Routledge 2003).

Johnston, L and P Stenning, 'Challenges of governance and accountability for transnational private policing' in F Lemieux (ed.), International Police Co-operation: Emerging issues, theory and practice 281-297 (Willan Publishing 2010).

Jones, T and T Newburn (eds), Plural Policing: A Comparative Perspective (Routledge 2006).

Kakalik and S Wildhorn, Private Police in the United States (5 vols, Rand Corporation 1971-72). Kempa, M, P Stenning and J Wood, 'Policing communal spaces: a reconfiguration of the Mass Private Property hypothesis’ (2004) 44(4) British Journal of Criminology 562. 
Klausen, J 'British Counter-Terrorism after 7/7: Adapting Community Policing to the Fight Against Domestic Terrorism’ (2009) 35(3) Journal of Ethnic and Migration Studies 403. Klockars, C, The Idea of Police (Sage Publications 1985).

Loader, I, 'In Search of Civic Policing: Recasting the "Peelian” Principles' (2016) 10(3) Criminal Law and Philosophy 427.

Loader, I, 'Plural Policing and Democratic Governance' (2000) 9(3) Social \& Legal Studies 323.

Loader, I and N Walker, Civilizing Security (Cambridge University Press 2007).

Loader, I and A White, 'How can we Better Align Private Security with the Public Interest? (2017) 11, Regulation \& Governance 166.

Lodge, E, 'Regulation of Private Police' (1967) 40(3) Southern California Law Review 540.

Macaulay, S. 'Private Government' in L Lipson and S Wheeler (eds), Law and the Social Sciences 445-518 (Russell Sage Foundation 1986).

Mann, S, J Fung and R Lo, 'Cyborglogging with camera phones: steps toward equiveillance' in Proceedings of the 14th ACM International Conference on Multimedia 177-180 (ACM 2006). McClintock, F and P Wiles (eds), The Security Industry in the United Kingdom (Institute of Criminology, University of Cambridge 1972).

Momboisse, R, Industrial Security for Strikes, Riots and Disasters (Charles Thomas 1968).

Nalla, M and G Newman, 'Public versus private control: a reassessment' (1991) 19(6) Journal of Criminal Justice 537.

New York State Legislature, Committee on Privacy of Communications and Licensure of Private Detectives, Reports (New York State Legislature 1957 \& 1958).

Paine, D, Industrial Security (Oak Security, Publications Division 1972).

Parker, Christine, Colin Scott, Nicola Lacey, and John Braithwaite. 2004. "Introduction.” Pp. 112 in Regulating Law, edited by C. Parker, C. Scott, N. Lacey, and J. Braithwaite. Oxford:

Oxford University Press.

Pinkerton, A, Professional Thieves and the Detective (first published 1881, reprinted in 'Foundations of Criminal Justice Series', AMS Press Inc. 1933).

Pinkerton, A, Strikers, Communists, Tramps and Detectives (first published G. W. Carlton \& Co. 1878 reprinted in 'Mass Violence in America Series' Arno Press).

Pleece, S, 'The Nature and Potential of the Security Industry' (1972) XLIV(1) Police Journal 46. 
Prenzler, T and R Sarre, 'Regulation' in M Gill (ed.), The Handbook of Security 857-878 (Palgrave Macmillan 2014).

Raustiala, K, 'Governing the Internet' (2016) 110(3) The American Journal of International Law 491.

Rees, A, (ed.), Policing and Private Security (Australian Institute of Criminology 1983).

Reiner, R, The Politics of the Police (4th edn, Oxford University Press 2010).

Rigakos, G, The New Parapolice: Risk Markets and Commodified Social Control (University of Toronto Press 2002).

Ruteere, M, C Shearing and P Stenning, 'Human Rights and Pluralization of Policing' in L Weber, E Fishwick and M Marmo (eds), The Routledge International Handbook of Criminology and Human Rights 396-404 (: Routledge 2016).

Ryan, B, 'Northern Ireland's District Policing Partnerships and the Participatory Ideals' (2008) 23(3) Irish Political Studies 341.

Scott, T and M McPherson, 'The Development of the Private Sector of the Criminal Justice System' (1971) 6(2) Law and Society Review 26.

Shalloo, J, Private Police, with Special Reference to Pennsylvania (first published 1933, reprinted in 'Criminology, Law Enforcement and Social Problems Series, 199, Patterson Smith 1973).

Shearing, C and P Stenning (eds), Private Policing (Sage 1987).

Shearing, C and P Stenning, 'From the Panopticon to Disney World: The Development of Discipline' in A Doob and E Greenspan (eds), Perspectives in Criminal Law 335-349 (Canada Law Book Co. 1984).

Shearing, C and P Stenning, Private Security and Private Justice: The Challenge of the 80's (The Institute for Research on Public Policy 1982).

Shearing, C and P Stenning, 'Modern private security: its growth and implications' in M Tonry and N Morris (eds), Crime and Justice - An Annual Review of Research, vol. III, 193-245 (University of Chicago Press 1981).

Shearing, C and P Stenning, 'The Quiet Revolution: The Nature, Development and General Legal Implications of Private Security in Canada' (1980) 22 (Canadian) Criminal Law Quarterly 220.

Shearing, C, P Stenning and S Addario, 'Corporate Perceptions of Private Security' (1985) 9(4) Canadian Police College Journal 367. 
Shearing, C, P Stenning and S Addario, 'Police Perceptions of Private Security' (1985) 9(2) Canadian Police College Journal 127.

Shearing, C and J Wood, 'Nodal governance, democracy and the new "denizens"' (2003) 303(3) Journal of Law and Society 400.

Sheptycki, J (ed.), Issues in Transnational Policing (Routledge 2000).

Sparrow, M, 'Managing the Boundary Between Public and Private Policing' in New Perspectives in Policing Bulletin (US Department of Justice, National Institute of Justice 2014).

Spitzer, S and A Scull, 'Privatization and capitalist development: the case of the private police' (1977) 25(1) Social Problems 18.

Steinberg, S, 'Private Police Practices and Problems' (1972) 4 Law and the Social Order 585.

Stenning, P, 'Governance and Accountability in a Plural Policing Environment - The Story So Far’ (2009) 3(1) Policing - A Journal of Policy and Practice 22.

Stenning, P, 'Powers and Accountability of Private Police' (2000) 8 European Journal on Criminal Policy and Research 325.

Stenning, P, 'Reclaiming the Policing Agenda - A Proposal for Change'. Unpublished presentation to the Metropolitan Toronto Anti-Racism, Access and Equity Committee, 11September 1997. (Copy available from the author).

Stenning, P and M Cornish, The Legal Regulation and Control of Private Policing in Canada (Centre of Criminology, University of Toronto 1975).

Stenning, P and C Shearing, 'Corporate Security: Some Preliminary Thoughts' (1984) 17(2) Australian and New Zealand Journal of Criminology 79.

Stenning, P and C Shearing, 'The shifting boundaries of policing: globalization and its possibilities' in T Newburn and J Peay (eds), Policing: Politics, Culture and Control 265-284 (Hart Publishing 2012).

The Economist, 'Rating police officers: how one family of high school students is policing the cops" The Economist (2 January 2016) $25<\underline{\text { http://www.economist.com/news/united- }}$ states/21684818-how-one-family-high-school-students-policing-cops-revenge-nerds $>$.

Thurston, J, 'The Authority and Powers of Security Officers' (Unpublished paper delivered at the annual Crime in Industry seminar, Hamilton, Ontario, 1969).

United States Senate, Committee on Education and Labor Private Police Systems (Lafollette Hearings) Reprint of Violations of Free Speech and Rights of Labor (U.S. Government Printing Office (1939/1971)); reprinted by Arno Press and The New York Times, New York, 1971. 
Van Steden, R and R Sarre, 'The Growth of Privatized Policing: Some Cross-national Data and Comparisons' (2007) 31(1) International Journal of Comparative and Applied Criminal Justice 51.

Vollmer, A, The Police and Modern Society (University of California Press 1936).

Wall, D and M Williams, 'Policing cybercrime: networked and social media technologies and the challenges for policing' (2013) 23(4) Policing and Society 409.

Weiss, R, 'From "Slugging Detectives" to "Labor Relations": Policing Labor at Ford, 19301947' in C Shearing and P Stenning (eds), Private Policing 110-130 (Sage 1987).

Williams, D, 'Crime Prevention and Private Security: Problems of Control and Responsibility' (1974) 48 Australian Law Journal 381. 